\title{
Development of scientific and technical potential in the member states of the Eurasian Economic Union
}

\author{
Arthur Gibadullin ${ }^{1 *}$, Valentina Pulyaeva ${ }^{2}$, Tufa Usmanova $^{3}$, Irina Ivanova $^{2}$, and Larisa \\ Vlasenko ${ }^{4}$ \\ ${ }^{1}$ State University of Management, 99, Ryazan Avenue, Moscow, 109542, Russian Federation \\ ${ }^{2}$ Financial University under the Government of the Russian Federation, 49, Leningradskiy avenue, \\ Moscow, 125993, Russian Federation \\ ${ }^{3}$ The Technological University of Tajikistan, 63/3, N. Karaboev, Dushanbe, 734055, The Republic of \\ Tajikistan \\ ${ }^{4}$ Moscow State University of Civil Engineering, 26, Yaroslavskoye Shosse, Moscow, 129337, \\ Russian Federation
}

\begin{abstract}
The purpose of the article is the analysis and development of scientific and technological potential in the member states of the Eurasian Economic Union. In the presented material, based on the use of the system analysis method, the scientific and technical potential of the Member States of the Eurasian Economic Union was investigated. Then, using the logical method, it was revealed that the number of research centres was reduced, the volume of internal costs for research and development was reduced, and the number of personnel employed in the scientific and technical field was reduced. In the study, using statistical and comparative methods, it was found that up to $90 \%$ of the scientific and technical potential is concentrated in the Russian Federation. The paper analyzed the digital transformation of national economies, which established that states have digital potential, created conditions for its development, but there is an uneven distribution of innovative and digital infrastructure in the territory of the Eurasian Economic Union, which complicates the development of scientific and technological potential. In the study, using factor analysis, a conceptual model for the development of scientific and technological potential was proposed, which will ensure a rational and effective policy in the field of innovative and digital development of the member states of the Eurasian Economic Union. In the ending of the study the main conclusions and results of the work are presented.
\end{abstract}

\section{Introduction}

The development of new bilateral relations between companies, states and countries goes to a new level of relations and requires the parties to take into account the needs of all members of the alliance [1]. Companies, when combined, create network structures,

* Corresponding author: 11117899@mail.ru 
corporations, holdings, and interaction at the level of different states is expressed in the creation of multinational companies, while forming completely new approaches and technologies for introducing a business. Such experience pushed the countries of the world to create various integration groups that are aimed at developing a common economic, humanitarian, innovative, digital and other strategy to improve the efficiency of the national economy $[2 ; 3]$. In the framework of continental cooperation, world alliances are being created, the essence of which is to combat international terrorism, ensure sustainable development, preserve the climate and natural resources for future generations, reduce uncontrolled economic and political consequences on states and more [4].

The Russian Federation actively participates in various supranational integration processes, the last of which is the creation of the Eurasian Economic Union of the Republic of Armenia, the Republic of Belarus, the Republic of Kazakhstan, the Republic of Kyrgyzstan and the Russian Federation (EAEU). Within the EAEU, free markets for goods and services have been created, free flows of capital and labor have been ensured, and it is planned to create markets for fuel and energy resources, pharmaceuticals, financial services, etc $[5 ; 6]$. In the opinion of the authors of the study, it seems necessary to analyze the scientific and technical potential of the EAEU member states, the willingness of states to digital transformation and propose mechanisms to increase the efficiency of use and development of scientific and technical potential within the EAEU.

\section{Materials and methods}

The purpose of this article is to assess the scientific and technological potential of the EAEU, its readiness for digital transformation and the development of mechanisms to improve the efficiency of the EAEU innovative activities. To achieve this goal, the following tasks:

- assess the scientific and technological potential of the member states of the Eurasian Economic Union and the conditions of digital transformation;

- develop mechanisms for the development of the scientific and technical potential of the EAEU.

The study used methods of statistical, logical, factorial, economic, comparative and system analysis, which allowed the authors to solve the goal and objectives of the study.

\section{Results}

An analysis of the scientific and technological potential of the member states of the Eurasian Economic Union showed that from 2015 to 2018, the number of organizations performing research work decreased by about $10 \%$. Established, that in all states of the Union, state research institutes and centres', the business sector and higher educational institutions carries out scientific research [7].

When assessing the costs of research, it was found that this indicator is reduced, and the source of investment is government funds, as well as own funds of organizations. Thus, we can conclude that the state is not only the initiator of research activities, but also the main source of funding for this type of work. In addition, in the Republic of Armenia, the Republic of Kazakhstan and the Russian Federation, the number of personnel employed in research and development is decreasing, and in the Republic of Belarus and the Republic of Kyrgyzstan, their number is increasing [7-9].

The study found that the Russian Federation has about $90 \%$ of the total scientific and technical potential of the member states of the Eurasian Economic Union, therefore, any changes in the Russian Federation affect the overall performance of the EAEU member 
states. In addition, both common and unique objects of scientific and innovative infrastructure are concentrated in Russia, which create the scientific and technical potential of the state, and, as a result, the scientific and technical potential of the Eurasian Economic Union $[7 ; 10 ; 11]$.

In addition to the development of innovative infrastructure, today they are paying attention to digitalization, which should ensure the development of the scientific and technical potential of national states and the EAEU as a whole. At the end of 2016, the states adopted the digital agenda of the Eurasian Economic Union, within the framework of which they set the tasks of converging and developing common regulatory legal acts in the field of digitalization, preserving intellectual property, creating various forms of cooperation between public and private structures, supporting and developing digital initiatives. Of course, for the purpose of digital transformation, basic technologies have been selected, which include the development of the Internet of things system, the creation of artificial intelligence, unmanned technologies, etc., and within the framework of the states, the potential for digital transformation of the industry and the economy as a whole is being identified [12-14]. Therefore, for example, in states there is the following potential and companies that are engaged in digitalization at the state level:

- high technologies are developed in the Republic of Armenia and about 400 firms are located, republican innovation centres' and incubators are created;

- the Republic of Belarus is actively developing programming, republican companies in the field of digital technologies have been created and the largest park of high information technologies is functioning

- laboratories have been established in the Republic of Kazakhstan that are engaged in the development of cloud computing, mobile technologies, etc., a fleet of innovative technologies is functioning;

- in the Republic of Kyrgyzstan there are specialists in offshore programming and a high-tech park has been created;

- in the Russian Federation the number of specialists in the field of information technology is many times greater than in other states; moreover, their qualifications are much higher than those of specialists from other countries. In Russia, various research centres', innovation parks and other innovative infrastructure have been created $[15 ; 16]$.

The existing potential in the states is used exclusively for the development of their own industry, healthcare, education and other types of economic activity, however, within the framework of the EAEU, systemic projects have been developed that are aimed at creating smart factories, plants, cities, transport systems, houses, energy facilities and etc. Of course, the implementation of these projects is a global trend, and requires states to address the issues raised, however, in the opinion of the authors of the study, the transition to innovative and digital technologies should occur within the entire EAEU, and not just individual states. In this regard, in order to effectively develop the scientific and technical sphere, it is necessary to determine the systemic problems that currently exist within the Union:

- uneven distribution of innovative and digital potential in all countries of the union;

- lack of readiness of national economies for digital transformation;

- lack of necessary financial, human and material resources for the innovative and digital transition of national economies $[17 ; 18]$.

Thus, in order to ensure a sustainable transition to innovative and digital technologies, it is necessary to combine the scientific and technical potential of the EAEU member states in order to develop a common strategy, create a unified base of innovative and digital technologies, create training programs and professional development for the digital economy and create innovative infrastructure in the territory of the Eurasian Economic Union. 


\section{Discussions}

Let us present a conceptual model for the development of the scientific and technical potential of the Eurasian Economic Union, containing mechanisms for the formation of a unified strategy for the innovative and digital transition of national economies and the economy of the Eurasian Economic Union as a whole (figure) [19; 20].

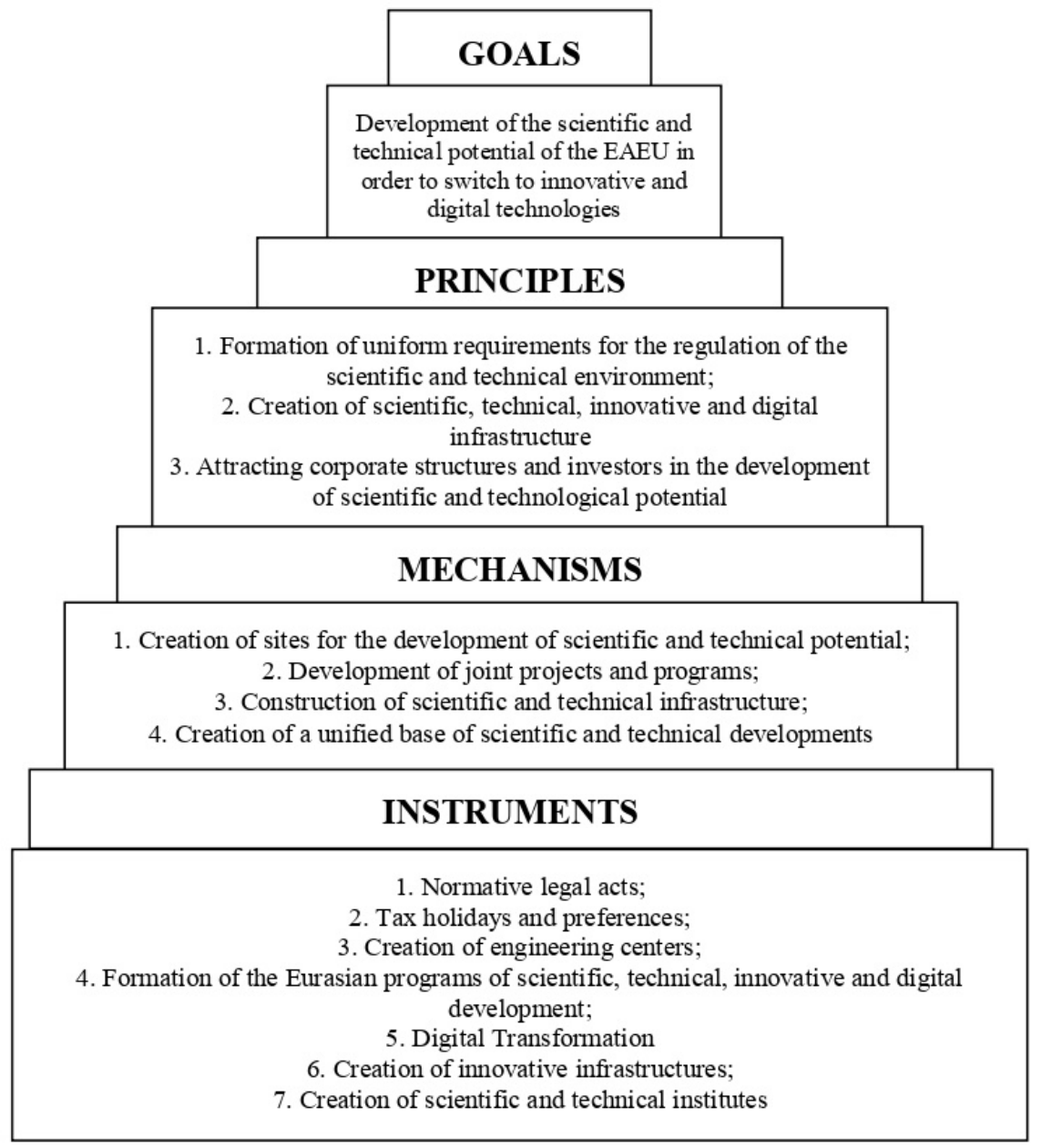

Fig. 1. A conceptual model for the development of the scientific and technological potential of the member states of the Eurasian Economic Union.

Thus, the presented conceptual model for the development of the scientific and technical potential of the member states of the Eurasian Economic Union will allow to determine the general requirements for the formation and development of innovative and digital technologies, as well as to ensure the convergence of the existing infrastructure and the creation of new research centers.

\section{Conclusion}

As part of the study, the main potential of the scientific and technical sector of the member states of the Eurasian Economic Union was analyzed. Established, that the main indicators 
characterizing the number of organizations, costs and headcount decrease annually. In addition, the innovative and digital infrastructure in the EAEU is unevenly located, for example, $90 \%$ of the research potential is concentrated in the Russian Federation, which makes it impossible to effectively switch to innovative and digital technologies within the EAEU. The study proposed a conceptual model that ensures the development of the scientific and technical potential of the member states of the Eurasian Economic Union with the aim of an effective transition to innovative and digital technologies.

\section{References}

1. A. Gibadullin, V. Pulyaeva, E3S Web of Conferences, 114, 02002 (2019) DOI: https://doi.org/10.1051/e3sconf/201911402002

2. E.V. Ganina, N.M. Malyugina, R.I. Polyakova, E.A. Fedorova, O.N. Bykova, International Journal of Engineering and Advanced Technology, 9(1), 5565-5569 (2019) DOI: 10.35940/ijeat.A2128.109119

3. J.V. Gnezdova, E.N. Rudakova, O.P. Zvyagintseva, Studies in Systems, Decision and Control, 169, 211-218 (2019) DOI: 10.1007/978-3-319-94310-7_21

4. V.I. Tinyakova, V.V. Davnis, E.V. Miroshnikov, M.A. Chervontseva, I.Y. Proskurina, International Journal of Engineer-ing and Advanced Technology, 8, 6, 2, 1107-1111 (2019) DOI: 10.35940/ijeat.F1327.0886S219

5. G.V. Butkovskaya, E.V. Sumarokova, E-management, 2, 3, 48-57 (2019) DOI: 10.26425/2658-3445-2019-3-48-57

6. D.S. Lopatkin, T.N. Shushunova, G.E. Shaldina, A.A. Gibadullin, I.L.Smirnova, Journal of Physics: Conference Series, 1399, 033061 (2019), DOI:10.1088/17426596/1399/3/033061

7. Y.N. Linnik, V.Y. Linnik, A.B. Zhabin, A.V. Polyakov, Mining Informational and Analytical Bulletin, 8, 33-41 (2019) DOI: 10.25018/0236-1493-2019-08-0-33-41

8. A.A. Gibadullin, M.I. Sadriddinov, Z.M. Kurbonova, Yu.N. Shedko, V.V. Shamraeva, IOP Conference Series: Earth and Environmental Science, 421, 032051 (2020) DOI: $10.1088 / 1755-1315 / 421 / 3 / 032051$

9. D.I. Zimnukhova, G.A. Zubkova, D.E. Morkovkin, P.V. Stroev, A.A. Gibadullin, Journal of Physics: Conference Series, 1399, 033097 (2019), DOI:10.1088/17426596/1399/3/033097

10. Statistical Yearbook of the Eurasian Economic Union; Eurasian Economic Commission. Moscow: 2019438 p

11. V.N. Zakharov, V.Y. Linnik, Y.N. Linnik, E.A. Averin, Eurasian Mining, 1, 40-42 (2019) DOI: 10.17580/em.2019.01.10

12. S.V. Bryukhovetskaya, K.A. Artamonova, A.A. Gibadullin, S.A. Ilminskaya, Z.M. Kurbonova, IOP Conference Series: Earth and Environmental Science, 421, 042018 (2020) DOI: 10.1088/1755-1315/421/3/042018

13. A. Sozontov, M. Ivanova, A. Gibadullin, E3S Web of Conferences, 114, 01009 (2019) DOI: https://doi.org/10.1051/e3sconf/201911401009

14. E.V. Kulyasova, N.S. Kulyasov, A.Yu. Puchkov, Journal of Physics: Conference Series, 1260, 032024 (2019) DOI: 10.1088/1742-6596/1260/3/032024

15. V.V. Davnis, V.I. Tinyakova, V.A. Fetisov, M.A. Chervontseva, S.I. Oparina, International Journal of Recent Technology and Engineering, 8, 3, 254-260 (2019) DOI: $10.35940 /$ ijrte.C1059.1083S19 
16. D.E. Morkovkin, Ch.V. Kerimova, O.I. Dontsova, A.A. Gibadullin, Journal of Physics: Conference Series, 1399, $033042 \quad$ (2019) DOI:10.1088/17426596/1399/3/033042

17. S. Miloslavskaya, A. Panychev, A. Myskina, P. Kurenkov, E. Rudakova, IOP Conference Series: Materials Science and Engineering, 698(6), 066065 (2019) DOI: 10.1088/1757-899X/698/6/066065

18. I.A. Ivanova, V.N. Pulyaeva, L.V. Vlasenko, A.A. Gibadullin, B.G. Safarov, IOP Conference Series: Earth and Environmental Science, 421, 032039 (2020) DOI: 10.1088/1755-1315/421/3/032039

19. S.A. Tolkachev, A.A. Bykov, D.E. Morkovkin, O.I. Borisov, A.V. Gavrilin, IOP Conference Series: Earth and Environmental Science, 421, 032041 (2020) DOI: 10.1088/1755-1315/421/3/032041

20. D.E. Morkovkin, Sententia. European Journal of Humanities and Social Sciences, 1, 41-47 (2019) DOI: 10.25136/1339-3057.2019.1.26990 